\title{
Relationships between VA Mycorrhizal Fungi and Plant Cover Following Surface Mining in Wyoming
}

\author{
MARCO E. WAALAND AND EDITH B. ALLEN
}

\begin{abstract}
Spoil spore counts of vesicular arbuscular mycorrhizal (VAM) fungi, VAM root infection, and percent cover of plants were assessed on reclaimed soil and spoil (1-6 years old), orphan spoil (10-31 years old), and undisturbed native sites. There was no relationship of site age with spore densities. Topsoiled sites almost always had significantly higher spore counts than spoil sites (reclaimed or orphan), indicating the importance of substrate on spore colonization and reproduction. Percent root infection of Agropyron smithii and $A$. dasystachyum showed no increasing trends with time in the mined sites (1-31 years), but the plants in the undisturbed site had greater infection than in any of the mined sites. There was also no correlation between percent cover of Agropyron and root infection or spore counts. These results suggest that time since disturbance is not an adequate explanation for the development of VAM infection and spore counts during the first 31 years, but that other factors such as the kind of substrate may be more important considerations.
\end{abstract}

\section{Key Words: mine spoils, mycorrhizal infection}

The disturbance of land by surface mining has reduced or eliminated vesicular-arbuscular mycorrhizae (VAM) from many soils in the arid west (e.g., Williams and Allen 1984, Call and McKell 1982,

Authors are former graduate student and research assistant professor, Department of Range Science and Ecology Center, Utah State University, Logan 84322-5230.

This project was funded by USDA grant nos. 83-CRCR-1-1229 and 83-CRSR-22274, and in part by N.S.F. Grant DEB 81-01827. The Kemmerer Coal Mine of the Pittsburg and Midway Coal Mining Company generously allowed the use of their land for this study.

We thank Michael F. Allen, James A. MacMahon, and Neil E. West for their advice during various stages of this research.

Manuscript accepted 17 February 1987
Allen and Allen 1980). VAM are normally abundant in arid soils (Trappe 1981), where they are important because they may increase growth, survival, and water and nutrient uptake by plants (M. Allen 1984, Aldon 1975).

It has been hypothesized recently that the abundance of VAM may determine the rate of succession in mined lands (Reeves et al. 1979, E. Allen 1984a, 1984b). Janos (1980) proposed that large scale disturbances will initially be colonized by nonmycorrhizal plants followed by facultatively mycorrhizal plants (species not needing VAM for survival), and then oligately mycorrhizal plants (species requiring VAM). During this transition the abundance of VAM inoculum in the soil should increase until a steady state plateau is reached. Although Janos'(1980) model was proposed for a tropical ecosystem, it may apply to succession after mining in the semiarid West. Many of the annuals which colonize these sites do not form mycorrhizae (Allen and Allen 1980), later seral species tend to be facultatively mycorrhizal, and some shrubs approach, although probably are not at, the obligately mycorrhizal end of the continuum (Lindsey 1984, E. Allen 1984a). Our objectives were to examine the relationships between plant cover, mycorrhizal root infection, and mycorrhizal spore density in some reclaimed and orphan (abandoned without reclamation) mine sites of different ages, and in some native undisturbed sites. We examined plants which were dominant at different seral stages, including annuals, grasses and shrubs.

\section{Materials and Methods}

The sampling sites were located at the Kemmerer Coal Mine near Kemmerer, Lincoln County, in SW Wyoming. Elevations of the sites vary from $2,000-2,700 \mathrm{~m}$ and the area receives approximately $24 \mathrm{~cm}$ precipitation annually. Precipitation during 1983, 
Table 1. Mean values (S.E.M.) for edaphic characteristics of reclaimed, orphan, and native sites at the Kemmerer Coal Mine.

\begin{tabular}{|c|c|c|c|c|c|}
\hline & \multirow[b]{2}{*}{ Reclaimed topsoil } & \multirow[b]{2}{*}{ Reclaimed spoil } & \multirow[b]{2}{*}{ Orphan spoil } & \multicolumn{2}{|c|}{ Native ${ }^{1}$} \\
\hline & & & & East & West \\
\hline$P(\mathrm{mg} / \mathrm{kg})$ & $23.7(1.3)$ & $18.3(2.1)$ & $19.73(2.6)$ & $33.6(7.9)$ & $25.4(3.2)$ \\
\hline$\% \mathrm{~N}$ (total) & $0.16(.01)$ & $0.20(0.3)$ & $0.25(.03)$ & $0.64(.04)$ & $0.17(.03)$ \\
\hline pH & $7.51(.17)$ & $6.83(.12)$ & $6.47(.23)$ & $6.5(.32)$ & $6.7(.21)$ \\
\hline$\%$ organic matter & $6.44(.67)$ & $9.0(.84)$ & $18.3(1.6)$ & $21.2(3.2)$ & $4.8(0.6)$ \\
\hline$\%$ sand & $39.6(2.6)$ & $23.9(4.0)$ & $4.3(1.9)$ & $13.3(1.3)$ & $39.3(10.9)$ \\
\hline$\%$ silt & $35.2(1.6)$ & $41.1(0.9)$ & $23.2(2.7)$ & $32.7(1.4)$ & $22.7(5.8)$ \\
\hline \% clay & $27.6(1.9)$ & $30.3(1.0)$ & $64.8(9.9)$ & $54.0(2.3)$ & $38.0(1.3)$ \\
\hline bulk density $\left(\mathrm{g} \mathrm{cm}^{-3}\right)$ & $1.15(.02)$ & $1.11(.01)$ & $1.10(.02)$ & $0.54(.23)$ & $1.60(.19)$ \\
\hline
\end{tabular}

'The means of east and west aspects are given for native sties only, as there were no differences in trends of edaphic factors on different aspects of mined sites.

the year of sampling, was $60 \mathrm{~cm}$. The native vegetation is a shrubgrassland (Parmenter et al. 1985).

Reclaimed topsoil, reclaimed spoil, orphan spoil, and native sites were sampled. Topography of reclaimed sites, created by heavy equipment, had been designed to reproduce previous contours. The topsoil applied to reclaimed sites had been stockpiled for 5-7 years. Reclaimed sites were seeded with Agropyron smithii Rydb., A. dasysachyum (Hook.) Scribn., A. spicatum (Pursh) Scribn. \& Smith, A. trachycaulum Link (Malte), Artemisia tridentata Nutt. and Atriplex canescens (Pursh.) Nutt. Orphan spoil, unreclaimed areas undergoing natural plant recolonization, were aprons of spoil material with the terminal tongues resting at the angle of repose facing east. Sampling was done on the upper convex slopes of all sites.

No sites reclaimed prior to 1977 were available, and seeding was not done in all years on either the topsoiled or spoil sites. The sites were chosen on the basis of uniform treatments and similar topography. Three reclaimed spoil sites were selected with seeding dates of 1978 (5-year-old spoil = S5), $1980($ S3), and 1981 (S2). Four topsoiled sites were chosen which had been seeded in 1977 (6-yearold topsoil = T6), 1980(T3), 1981 (T2), and 1982 (T1). Four orphan sites abandoned in different years were sampled. They are designated according to age, $\mathrm{O} 10, \mathrm{O} 18, \mathrm{O} 24$, and $\mathrm{O} 31$. Both east and west facing aspects were sampled for all sites except on T6 and 010 , which had an unvegetated highwall left by mining on the west facing side. The letters " $E$ " or " $W$ " added to a site name indicate east or west facing aspect.

Plant cover was estimated to the nearest $0.1 \%$ using a gridded $1.0 \times 0.5-\mathrm{m}$ quadrat frame. The frames were placed at 8 randomly chosen intervals along five $20-\mathrm{m}$ transects at each site. The 5 transects were located at different origins within each site. Origins were located on upper convex slopes with transects running parallel to the ridge on east and west aspects. No samples were taken closer than $10 \mathrm{~m}$ from the crest of ridges to avoid areas of windscoured bare ground. Percent cover data were averaged for the first and last 4 quadrats per transect. This resulted in 2 composite cover estimates per transect and a total of 10 per site.

Soil samples for mycorrhizal spore and edaphic analyses were taken from the center of each quadrat and these were also composited to reduce variability (Hayman 1984). Each soil sample from the reclaimed sites was a composite of subsamples from the first 4 quadrats in a transect for a total of 5 soil composites per site. Samples were taken to a depth of $10 \mathrm{~cm}$ with a hand trowel, placed in a plastic bag, and stored at $-10^{\circ} \mathrm{C}$ until analyzed. Root samples were similarly collected to assess root infection of individual $A$. smithii and $A$. dasystachyum plants from inside the quadrats. In summary, for each site, there were 5 composite soil samples, 5 composite spore samples, and 5 root samples each for the 2 grass species, i.e., a total of 65 soil and spore samples and 65 root samples per grass species for the reclaimed areas.

Sampling on orphan sites was not as clearly defined due to the patchiness of plant cover. At times fewer than 5 transects were run to the abbreviated lateral length of the spoil slope. In these instances fewer than 4 quadrats were averaged to arrive at a composite soil sample and cover estimate.

Roots of several abundant shrub species were sampled in addition to the grasses. These included Atriplex canescens in S3W and S5W, Chrysothamnus nauseosus (Pallas) Brit. and Artemisia tridentata on east-facing slopes of each of the orphan sites, $A$. tridentata on NE, and Artemisia arbuscula Nutt. on NW. Roots were excavated to $10 \mathrm{~cm}$ as for the grasses, and 5 replicate samples were taken for each species on each site. The shrubs on mined sites seldom fell on the transects, but they were collected as close to the transects as possible.

The native sites were chosen to have topography similar to that of the reclaimed areas. Cover estimates and soil samples were gathered in a manner similar to that for the reclaimed sites. Root samples in the native and orphan areas were taken outside the quadrat if the species of interest was not present along the transect. This was never a problem in reclaimed areas.

Spores were extracted from soil using sucrose flotation (M. Allen et al. 1979) and expressed as numbers per gram oven dry $\left(65^{\circ}\right.$ C) soil. Root samples were washed, stained, and mycorrhizal infection frequencies were determined as previously described (Kormanick et al. 1980). Fifty l-mm segments were scored for presence or absence of VAM for each root system.

Eight soil variables were measured. Nutrient status was measured using the micro-Kjeldahl method for N (Bremner and Mulvaney 1982), and the bicarbonate extraction method for $\mathrm{P}$ (Olsen and Sommers 1982). A soil paste with a 1:1 soil to water ratio was assessed for $\mathrm{pH}$. Bulk density was determined by weighing known volumes of dried soil cores. Organic matter percentage was estimated by dry combustion of soil. Sieving and the Bouyucous methods were used to assess soil texture.

Stepwise regressions were utilized to determine which factors best predicted differences in \% cover of $A$. smithii and $A$. dasystachuym. The independent variables were \% VAM root infection, spore density, $\%$ sand, silt and clay, total $\mathrm{N}$, extractable $\mathrm{P}, \mathrm{pH}, \%$ organic matter, and bulk density. Because this is a "pseudoreplicated" experiment (Hurlbert 1984) where age is represented by 1 replicate site, the remaining data analysis includes only calculations of standard errors, and the results are presented in terms of trends in plant cover or VAM with respect to age of the sites since reclamation or abandonment.

\section{Results}

The 8 edaphic factors which were measured showed some differences in value by site (Table 1). There were no apparent trends in values of any of the factors due to increased age on the reclaimed or orphan sites. The native east (NE) aspect had both higher $\mathrm{N}$ and $\%$ organic matter than all other sites. Microscopic examination of both orphan and reclaimed spoil showed that most of the organic matter was coal, but little coal was found in native or reclaimed topsoil. The high percentage of noncoal organic matter in the NE site probably contributed to its low bulk density. Clay was exceptionally high and sand low in the orphan spoils.

The various species and groups of species showed differing trends in abundance among the sites. Annuals were most abundant 

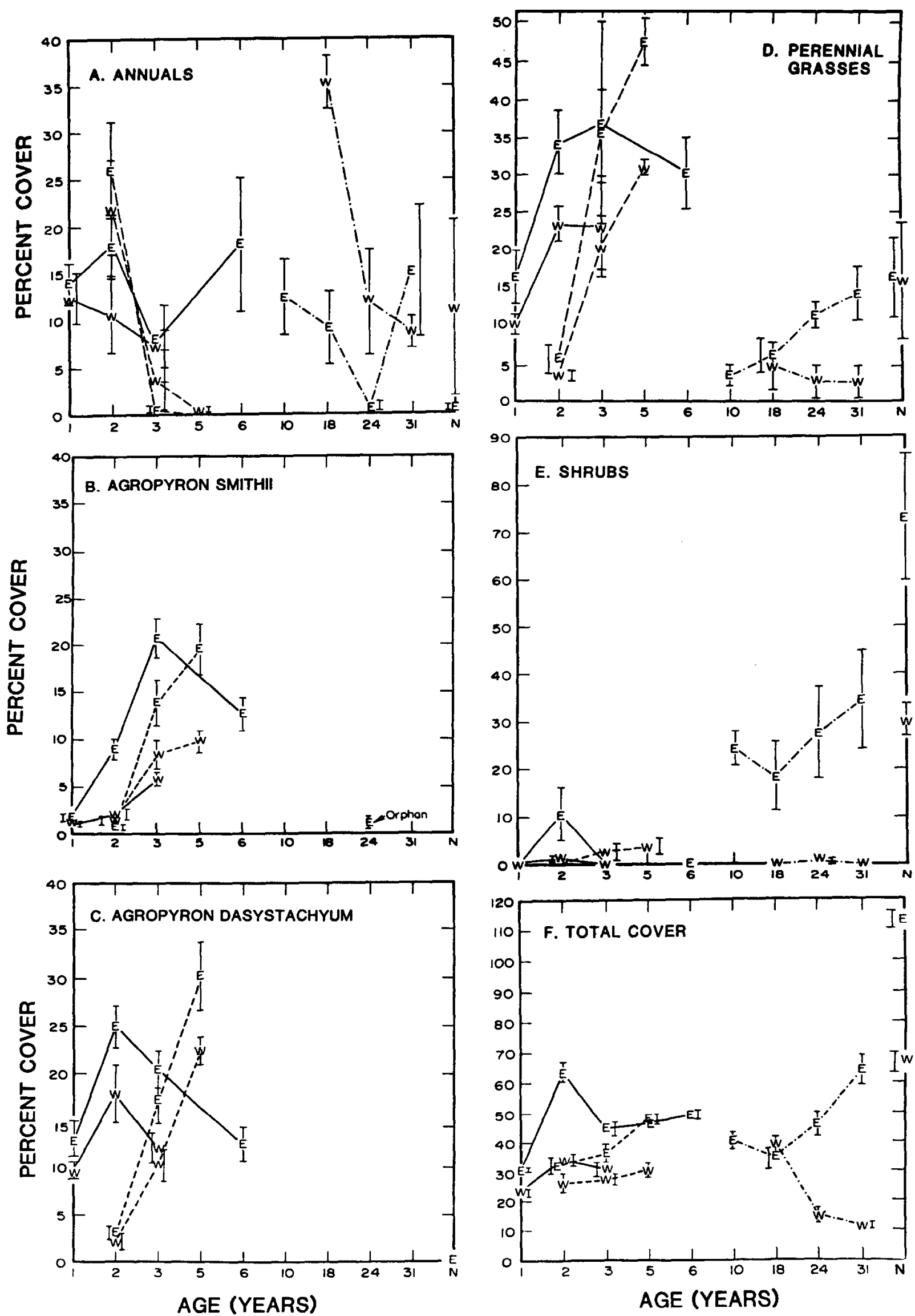

Fig. 1. Changes in \% cover of species or groups of species as indicated in A-F. The curves show reclaimed topsoil (1-6), orphan spoil (_-_) (years 10-31) and native undisturbed sites (N). East (E) and west (W) facing aspects are shown separately. The curves connect points to improve clarity, not to imply a continum. 
in recently reclaimed spoil and decreased rapidly with age, but there were no apparent trends with time for reclaimed topsoil or orphan sites (Fig. 1A). The annual species on reclaimed spoil were predominantly Chenopodiaceae (primarily Salsola kali L. with highest cover of $4 \%$ in S2W; and Kochia scoparia L., $18 \%$ cover in S2E) and Polygonum aviculare L. (15\% in S2E). On reclaimed topsoil the dominants were Brassicaceae (primarily Thlaspi arvense L. with highest cover of $5 \%$ in T1E; Descurainia sophia (L.) Webb ex Prantl., 9\% in T2W; and Lepidium perfoliatum L., 7\% in T6E) with some Salsola kali (3\% in TIE), and Bromus tectorum L. (6\% in $\mathrm{T} 3 \mathrm{~W})$. The dominant annuals at the orphan sites were $B$. tectorum ( $12 \%$ in $031 \mathrm{E}$ ) and $K$. scoparia (12\% in O24W). B. tectorum was the only annual found at the native west (NW) site. A detailed report on the abundance of each species at each site can be found in Waaland (1985).

Agropyron smithii (Fig. 1B) and A. dasystachyum (Fig. 1C) showed a trend of increased percent cover with time in reclaimed sites and had greater cover on east than west facing slopes. $A$. smithii, but not $A$. dasystachyum, colonized only 1 orphan site $(024 \mathrm{E})$, and both were absent from transects in the native site. However, $A$. smithii occurred infrequently in swales in the native area, and $A$. dasystachum occurred at mid-slope.

Percent total cover of perennial grasses generally increased with time on reclaimed sites (Fig. 1D), where the planted grasses $A$. trachycaulum, A. spicatum, A. smithii and A. dasytachyum (Figs. IB and 1C) were the dominants. On orphan sites grass cover was much greater on east than west facing slopes. Two grass species were important on the east aspect: Sitanion hystrix (Nutt.) J.G. Smith with highest cover of $7 \%$ in $\mathrm{O} 31 \mathrm{E}$, and Oryzopsis hymenoides (R. \& S.) Ricker with highest cover of $4 \%$ in both $\mathrm{O} 24 \mathrm{E}$ and O18E. Hordeum jubatum L. was the most important species on the west aspect, with greatest cover of $8 \%$ in $018 \mathrm{~W}$. The most abundant grass species at the native sites were Elymus cinereus Scribn. \& Merr. (10\% on NE) and S. hystrix (3\% on NW).

The general pattern apparent from cover of shrubs at all the sites is that they increased with time on east facing aspects (Fig. IE). What is not apparent from Fig. $1 \mathrm{E}$ is the shift in species composition. The reclaimed sites had primarily the planted Atriplex canescens with some Artemisia tridentata. Chrysothamnus nauseosus was the most common dominant shrub in orphan spoil and varied from $1 \%$ cover on $\mathrm{O} 31 \mathrm{E}$ to $29 \%$ on $\mathrm{O} 24 \mathrm{E}$, while $A$. tridentata varied from $0.1 \%$ on $\mathrm{O} 24 \mathrm{E}$ to $21 \%$ on $\mathrm{O} 31 \mathrm{E}$. Only $\mathrm{O} 24 \mathrm{~W}$ among the west facing aspects of the orphan sites had any shrubs, $C$. nauseosus with $0.3 \%$ cover. Finally, shrub cover on both east and west facing aspects of the native sites was at least double that for respective aspects of reclaimed and orphan sites (Fig. 1E). The dominant shrubs of the east aspect were Symphorocarpus oreophilus Gray (31\%), A. tridentata (18\%), Amelanchior alnifolia Nutt. (10\%), and Purshia tridentata Pursh (DC.) (5\%). The west aspect was dominated by Artemisia arbuscula (26\%).

Percent total cover was higher on east than west facing aspects as would be expected (Fig. 1F). There was no trend of increased percent cover with time in the reclaimed sites, and the west facing orphan sites had lower total cover than reclaimed sites. The high cover on east facing orphan sites could be attributed to shrub colonization. Cover of the native sites was higher than that of the respective aspects of any of the mined sites. The cover of NE was greater than $100 \%$ due to layering of the shrub and grass canopies.

There were no apparent trends in mycorrhizal root infection according to site age for either $A$. smithii or $A$. dasystachyum in the reclaimed sites (Fig. 2A and $2 B$ ). Infection of both was relatively high in the 1-year-old topsoiled site (T1), especially on west slopes. Neither time nor aspect appeared to change root infection in any predictable way on the mined sites. Root infection was, however, highest for $A$. dasystachyum on the native site, where it was not found on the transects but was collected at mid-slope.

Percent VAM root infection of the shrubs tended to be lower on the younger (reclaimed) than the older (orphan and native) sites
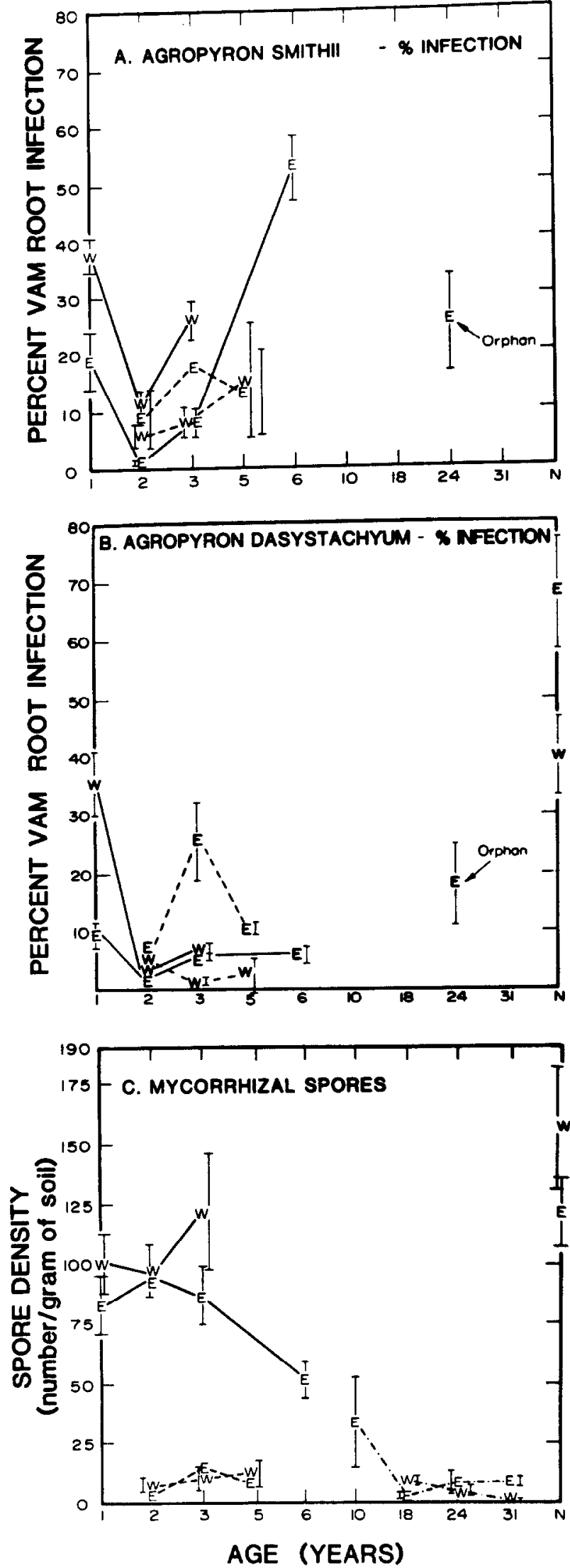

Fig. 2. Changes in \% of root infection by mycorrhizal fungifor Agropyron smithii $(A)$ and Agropyron dasystachyum (B), and mycorrhizal spore density ( $C)$. The curves show reclaimed topsoil (_), reclaimed spoil (---) (years 1-6), orphan spoil ( $-\bullet)$ (years 10-31) and native undisturbed sites (N). East $(E)$ and west $(W)$ aspects are shown separately. The curves connect points to improve clarity, not to imply a continuum. 
Table 2. Percent VAM root infection of shrubs from mined and native sites. $\mathrm{S}=$ reclaimed spoll, $\mathbf{O}=$ orphan site, $N=$ native site, $W=$ west facing slope, $\mathbf{E}=$ east facing slope, numbers are age of site since reclamation or abandonment.

\begin{tabular}{lcc}
\hline \hline Shrub species & $\%$ infection (S.E.M.) & Site \\
\hline Atriplex canescens & $7(3)$ & S3W \\
Chrysothamnus nauseosus & $10(3)$ & S5W \\
& $34(4)$ & O10E \\
& $50(7)$ & O18E \\
Artemisia tridentata & $30(11)$ & O24E \\
& $84(4)$ & O31E \\
& $41(3)$ & O10E \\
A. tridentata & $60(6)$ & O18E \\
Artemisia arbuscula & $32(11)$ & O24E \\
\hline
\end{tabular}

(Table 2), but there were different shrub species on the different sites.

The data on density of mycorrhizal spores show a trend in abundance according to substrate (Fig. 2C). Spore density is generally much lower in spoil (reclaimed or orphan) than in topsoil (reclaimed or native) sites. However, neither age nor aspect show any trends in spore counts.

Multiple regressions are presented only for the spoil and topsoil reclaimed sites, as a regression including all the sites was confounded by different treatments, substrates, and species. The coefficients entered into the following equations are each significant at $P=0.95$ :

$$
\begin{aligned}
& \text { Reclaimed Topsoil }(\mathrm{n}=35) \\
& \% \text { AS }=36.75+2.78 \text { TIME }-0.16 \text { ASRT - } \\
& 4.70 \mathrm{pH} ; \mathrm{R}^{2}=0.590 \text {, } \\
& \% \mathrm{AD}=17.98-0.26 \text { ADRT; } \mathrm{R}^{2}=0.123 \text {, } \\
& \text { Reclaimed Spoil }(\mathrm{n}=30) \\
& \% \text { AS }=-15.07+6.10 \text { TIME }-0.43 \text { SPORE; } \\
& R^{2}=0.620 \text {, } \\
& \% \text { AD } \quad=-9.76+6.48 \text { TIME; } R^{2}=0.718 \text {; } \\
& \% \text { AS } \quad=\% \text { cover of } A \text {. smithii, } \\
& \% \mathrm{AD}=\% \text { cover of } A \text {. dasystachyum, } \\
& \text { TIME = years since seeding, } \\
& \text { ASRT }=\text { mycorrhizal root infection of } \\
& \text { A. smithii, } \\
& \text { ADRT = root infection of } A \text {. dasystachyum, } \\
& \text { pH }=\text { soil } \mathrm{pH} \text {, } \\
& \text { SPORE = density of mycorrhizal spores } \\
& \text { in soil. }
\end{aligned}
$$

For both species TIME was the most frequent predictor of plant cover. There were only some weak negative, but no positive, relationships of root infection or spore density to plant cover; $\mathrm{pH}$ was the only edaphic factor to appear in the equations, not surprising in a study which was designed to minimize differences in edaphic factors.

\section{Discussion}

There was no gradual increase in VAM spore numbers after the soil was disturbed by mining in this semiarid shrub-grassland, as was predicted for other sites (Janos 1980, Reeves et al. 1979). The density of VAM spores was always lower in spoil than topsoil regardless of age of the site. Age of a site could also not be used to predict the percent VAM root infection of the 2 most abundant grasses on the reclaimed sites, Agropyron smithii and A. dasystachyum, and percent root infection was not significantly correlated with percent cover of these grasses. Only the native sites had higher percent infection of grasses, as well as shrubs, than any of the reclaimed sites. Other factors besides time may be important in determining root infection and spore numbers, such as soil fertility, organic matter, and texture (Allen and Allen 1980), patterns of migration of spores by wind in these complex terrains (Warner 1985), and production of infective propagules (spores, vesicles, and hyphae) by neighboring species (Miller et al. 1983, Allen and MacMahon 1985). The results may be due in part to the "pseudoreplicated" design. For instance, low spore counts and low plant cover in T6E may have been caused by failure of seeding equipment, as some drill rows clearly had no seeded vegetation. In spite of these variables, 2 general conclusions regarding VAM can be made. The kind of substrate appeared to be more important than time in determining conditions for spore inoculum during the initial 31 years, and low spore numbers in spoil did not result in lower infection of the Agropyron species than in topsoil.

Another way to examine the relationship of VAM to succession is to divide the plants into functional groups as suggested by Janos (1980). The early successional species were predominantly annual members of the Chenopodiaceae and Brassicaceae, which do not form mycorrhizae (Pendleton and Smith 1983). The Agropyron species are mid to late seral and formed moderate levels of infection, both where they had been planted and colonized naturally on mine spoil. The shrubs tended to have greater infection than cooccurring grasses with the exception of Atriplex canescens. To make any further conclusions from these observations, physological studies which show effects of VAM on these species in these soils would need to be done, and rates of VAM root infection with different soil inoculum levels would need to be assessed. These studies would provide the basis for a mechanistic understanding of the processes involved in plant and VAM establishment during succession. The initial establishment phase of succession is the most critical in arid lands, where there are few seral stages (MacMahon 1981). Once establishment of VAM has occurred, the substrate may be more important than time in determining the continued successional development of VAM.

\section{Literature Cited}

Aldon, E.F. 1975. Endomycorrhizae enhance survival and growth of four wing saltbush on coal mine spoils. USDA Forest Serv. Res. Note RM-294.

Allen, E.B. 1984a. The role of mycorrhizae in mined land diversity p. 273-295. In: 3rd Biennial Symp. on Surface Coal Mine Reclamation in the Great Plains. Billings, Mont.

Allen, E.B. 1984b. VA mycorrhizae and colonizing annuals: implications for growth, competition, and succession. p. 41-51. In: S.E. Williams and M.F. Allen eds. VA mycorrhizae and reclamation of arid and semiarid lands. Univ. of Wyoming Agr. Exp. Sta. Sci. Rep. No. SA 1261, Laramie.

Allen, E.B., and M.F. Allen. 1980. Natural re-establishment of vesiculararbuscular mycorrhizae following stripmine reclamation in Wyoming. J. Appl. Ecol. 17:139-147.

Allen, M.F. 1984. Physiology of mycorrhizae: a key to understanding successful plant establishment. p. 68-80. In: S.E. Williams and M.F. Allen eds. VA mycorrhizae and reclamation of arid and semiarid lands. Univ. of Wyoming Agr. Exp. Sta. Sci. Rep. No. SA 1261, Laramie.

Allen, M.F. and J.A. MacMahon 1985. Impact of disturbance on cold desert fungi: comparative microscale dispersion patterns. Pedobiologia 28:215-224.

Allen, M.F., T.S. Moore, M. Christensen, and N. Stanton. 1979. Growth of vesicular-arbuscular mycorrhizal and non-mycorrhizal Bouteloua gracilis in a defined medium. Mycologia 71:666-669.

Bremner, J.M., and C.S. Mulvaney. 1982. Nitrogen-total. p. 1238-1255 In: A.L. Page, R.H. Miller, and D.R. Keeney eds. Methods of soil analysis, Part 2-Chemical and microbiological properties. Amer. Soc. of Agron. and Soil Sci. Soc. of Amer. Madison, Wis.

Call, C.A. and C.M. McKell. 1982. Vesicular-arbuscular mycorrhizae-a natural revegetation strategy for disposed oil shale. Reclam. and Reveg. Res. 1:337-347.

Hayman, D.S. 1984. Methods for evaluating and manipulating VA mycorrhizae. J.M. Grainger and J.M. Lynch, eds. p. 95-117 In: Microbiological methods for environmental biotechnology. Academic Press, New York. 
Hurlbert, S.H. 1984. Pseudoreplication and the design of ecological field experiments. Ecol. Monogr. 54:187-211.

Janos, D.P. 1980. Mycorrhizae influence tropical succession. Biotropica 12:56-64

Kormanick, P.P., W.C. Bryan, and R.C. Schultz. 1980. Procedures and equipment for staining large numbers of plant root samples for endomycorrhizal assay. Can. J. Microbiology. 26:536-538.

Lindsey, D.L. 1984. The role of vesicular-arbuscular mycorrhizae in shrub establishment. p. 52-67. In: S.E. Williams and M.F. Allen eds. VA Mycorrhizae and reclamation of arid and semiarid lands. Univ. of Wyoming. Agr. Exp. Sta. Laramie.

MacMahon, J.A. 1981. Successional processes: comparisons among biomes with special reference to probable roles of and influences on animals. p. 277-304. In: D. West, H. Shugart and D. Botkin eds. Forest succession: concept and application. Springer Verlag, New York.

Miller, R.M., T.B. Moorman, and S.K. Schmidt. 1983. Interspecific plant association effects on vesicular-mycorrhizal occurrence in Atriplex confertifolia. New Phytol. 95:241-246.

Olsen, S.R., and L.E. Sommers. 1982. Phosphorous. p. 1035-1049 In: A.L. Page, R.H. Miller, and D.R. Keeney eds. Methods of soil analysis Part 2-Chemical and microbiological propertys. Amer. Soc. of Agron. and Soil Sci. Soc. of Amer. Madison, Wis.
Parmenter, R.R., J.A. MacMahon, M.E. Waaland, M.M. Steube, P. Landres, and C.M. Crisufulli. 1985. Reclamation of surface coal mines in western Wyoming for wildlife habitat. Reclam. Reveg. Res. 4:93-115.

Pendleton, R.L., and B.N. Smith. 1983. Vesicular-arbuscular mycorrhizae of weedy and colonizer plant species at disturbed sites in Utah. Oecologia 59:296-301.

Reeves, F.B., D. Wagner, T. Moorman, and J. Kiel. 1979. The role of endomychorrhizae in revegetation practices in the semi-arid west. I. A comparison of incidence of mycorrhizae in severely disturbed versus. natural environments. Amer. J. Bot. 66:6-13.

Trappe, J.W. 1981. Mycorrhizae and productivity of arid and semi-arid rangelands. p. 581-599. In: J.T. Manassah and E.J. Briskey eds. Advances in food producing systems for arid and semi-arid lands. Academic Press, New York.

Warner, N. 1985. Dispersal of VAM fungi in disturbed semi-arid ecosystems: the potential roles of biotic and abiotic agents. M.S. thesis, Utah State University, Logan.

Waakand, M.E. 1985. Correspondence of vesicular-arbuscular mycorrhizae with seral vegetation in southwestern Wyoming. M.S. thesis, Utah State University, Logan.

Williams, S.E., and M.F. Allen eds. 1984.VA mycorrhizae and reclamation of arid and semiarid lands. Univ. Wyoming Agr. Exp. Sta. Sci. Rep. No. SA 1261, Laramie. 